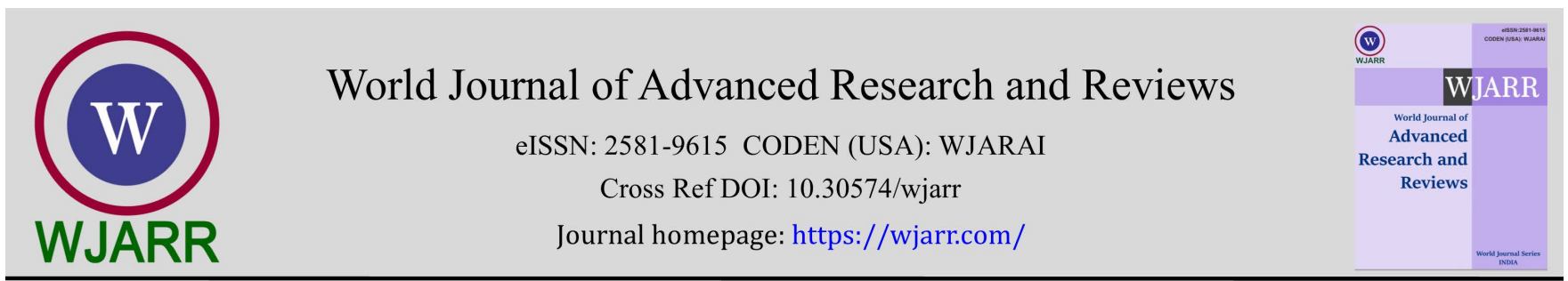

(RESEARCH ARTicle)

\title{
Insight of Ipomoea carnea and its use in wastewater treatment as ecofriendly, sustainable solution
}

\author{
Sagar Mukundrao Gawande * and Dilip D. Sarode \\ Department of General Engineering, Institute of Chemical Technology, Matunga, Mumbai-400019, Maharashtra, India.
}

World Journal of Advanced Research and Reviews, 2022, 13(02), 483-491

Publication history: Received on 15 January 2022; revised on 24 February 2022; accepted on 26 February 2022

Article DOI: https://doi.org/10.30574/wjarr.2022.13.2.0185

\begin{abstract}
Gross Domestic Product (GDP) of India is much less than the other developed countries. Any ordinary citizen in such developing countries spend their major part of earnings on personal health. Majority of diseases are caused by improper sanitation practices or unhygienic conditions. There is need of decentralized system for the domestic wastewater treatment to improve the same. On the other hand, lack of maintenance of existing sanitation infrastructure and availability of the skilled persons or technicians to operate the dedicated treatment units create, the additional gap in treatment facilities. The effective investment in maintenance of treatment facilities and training of operators will save millions of rupees on the healthcare expenditure of the country.

This research article will provide insights of Morning Glory (Ipomoea carnea) plant to be used in ecofriendly and sustainable domestic wastewater treatment. The article has several images captured through Scanning Electron Microscope (SEM) and conventional microscope along with android cell phones and cameras. This article will be useful to engineering fraternity to open up new area of applications of Ipomoea carnea in engineering applications.
\end{abstract}

Keywords: Ipomoea carnea; Nature Based Treatment; SEM; Ecofriendly; Sustainable

\section{Introduction}

Phytoremediation is a rapidly growing field. Day to day new and modified developments are carried out around the world. In last several decades it facilitated the variety of applications. In general phytoremediation includes the uptake of organic, inorganic and radionuclides through the plant system.

The major source of organic and inorganic pollutants are manmade and released into environment in the form of spills, chemicals, pesticides, herbicides. The excess release of these pollutants has adverse effects on human and environmental health. The removal of these pollutants from the environment needs high capital and operational cost. The adoption of plants to uptake and degrade these pollutants is an affordable and ecofriendly solution.

This research cum review article opens the new sight for application of the Ipomoea carnea (Morning Glory) in wastewater treatment system. The corresponding author collected the information about the species from in and around the study area as well as from the reputed published journal papers. The main objective of this research is application of identified plant species in plant based wastewater treatment by ecofriendly and sustainable manner.

The samples of identified species are collected from the arid, semi-arid areas including remote water logged areas in and around the study area. This research article has various colorful magnified, images to elaborate not only the inside structure of the Ipomoea carnea but also has outer observations. All the related images are classified into two figures as

\footnotetext{
* Corresponding author: Sagar Mukundrao Gawande

Department of General Engineering, Institute of Chemical Technology, Matunga, Mumbai-400019, Maharashtra, India.

Copyright $(2022$ Author(s) retain the copyright of this article. This article is published under the terms of the Creative Commons Attribution Liscense 4.0.
} 
figure 1 is for outer perspective and figure 2 is for inner perspective. The article has discussion and findings of other authors dealt with the same species in different applications. The author will elaborate the extensive view of the Ipomoea carnea (Morning Glory) and its biomass production which will be useful in economic enrichments in rural areas.

The plant has heart-shaped leaves that are rich green in color and has length around 6 to 9 inches. It can be easily grown from seeds which are toxic in nature and hazardous to cattle. It also has medicinal value as it contains a component identical to marsilin, a sedative and anti-convulsant, a glycosidic saponins has also purified from it with anticarcinogenic and oxytoxic properties [1]. The (Morning Glory) Ipomoea carnea Jacq is a member of convolvulaceae. It grows in tropical, semi tropical conditions and is a worm temperate species. Ipomoea carnea Jacq. Is shrubby perennial amphibious plant, some species has tubers, whereas others have caudiciform succulent and distinguishable from Convolvulus in stigma as not linearly divided and spiny pollen, extra floral, nectaries [2]. Ipomoea carnea as a wetland plant usually found in humid soil or shallow water. A number of adaptations have been proposed that may enable some species to grow under such hostile conditions. These plants are widely distributed in India and are fast-growing plants, adapt easily to various aquatic conditions, dominate quickly in a wetland community, and produce a monotypic stand. They play an important role in the extraction and accumulation of metals from waters [3]. The plant species are able to grow in exceptionally hostile conditions of low acidity, low nutrient content, water-logged, anaerobic environments, and elevated to metal absorptions [3]. Ipomoea Carnea L. and evaluated phytoextraction potential of Lead (Pb) and testified that both the plants show capacity to remove Lead (Pb) from the polluted wastewater [4]. Ipomoea Aquatica Forsk has ability to store $\mathrm{Pb}$ in its root and the lower part of stem. It has ability to spread by fragmentation through production of adventitious roots and lateral branches from nodes and raises the possibility of utilizing Ipomoea Aquatica for $\mathrm{Pb}$ phytoremediation from liquid effluent $[5,19]$. As an application view of Ipomoea Carnea its stems can be used in making paper, the swollen tubers ed. starch as for dang myun noodles in Korea, the natural fibers used in biodegradable plastic for Toyota cars, polyactic acid bio-plastic and alcohol source and the dried tubers has high levels of purging resin [2].

The species is recognized well all over the Indian continent, particularly along the bunds of farming fields. It is a localized wild plant and wherever it grows it leads over the associate species. In general, vegetation showed that this species formed pure or varied positions in practically all types of environments common in an urban situation, revealing its wide ecological fullness. The plant species shows luxuriant growth within the urban and rural areas, especially near slums or where deposition of disintegrated organic matter and dumping of domestic waste. This plant also grows in toxic waste, water logged areas and most importantly even on dry soils [6].

\section{Material and methods}

\subsection{Collection of species}

The sufficient number of species along with stems of Ipomoea Carnea are collected from arid, semiarid and water logged area as described in figure 1. The collected species are wrapped with moist jute bag on collection from site to maintain and avoid the reduction in natural cell and plant properties during shifting from site to laboratory. Before shifting to the planting pot i.e. experimental setup all collected sample species are immersed into the water of pH 6-7.5 at a depth of around 12 inches for 24 hours. The vertical immersion of the stem allow the species to get familiar with the room and laboratory environment and help to avoid shock phenomenon at the time of shifting to soil media.

\subsubsection{Planting and Cultivating}

The prepared soil media with moisture content of around $67 \%$ allows to shift the prepared stems of Ipomoea carnea. The stems are prepared in such a way that it has cut angle of around 45 degree at bottom of every stem of 6 to 8 inch high. Around 4-6 stems of mentioned size are planted in prepared media with stem to stem distance of about 3 inches in the rectangular pot. The experimental set up is kept under the controlled condition of $27-35^{\circ} \mathrm{C}$ temperature and around 62-68 \% humidity with direct exposure to the sun light.

At every regular interval, the observations of development in the planted stems are done. The developments and primary observations are presented here in tabulated form. The prepared stem samples were marked with labels and permanent marker to understand the variation in developments. The systematic observations for leaves, stem height and diameter, flowers and fruits are made as shown in figure 1.

\subsubsection{Observation}

The species are monitored closely observed during the experimentation. At the regular interval the monitoring and observations are noted for leaf, stem, and flowering and fruit developments. The monitored observations are noted in 
observation book, the schedule interval for leaf monitoring kept at two day, for stem monitoring three days whereas for flower and fruit it was kept as seven days. The changes in growth pattern had special attention to gain the insights for on field and in laboratory conditions. The welting and falling of leafs had been noted during the initial days after planting and adoption of lab and soil conditions. The new leafs were developed after 6-7 days after development of leaf stalks, the monitored length of leaf is around 10-12 mm. The similar observations for stem, flower and fruits are noted and addressed in figure 1 for outer observations and microscopic observations in figure 2.

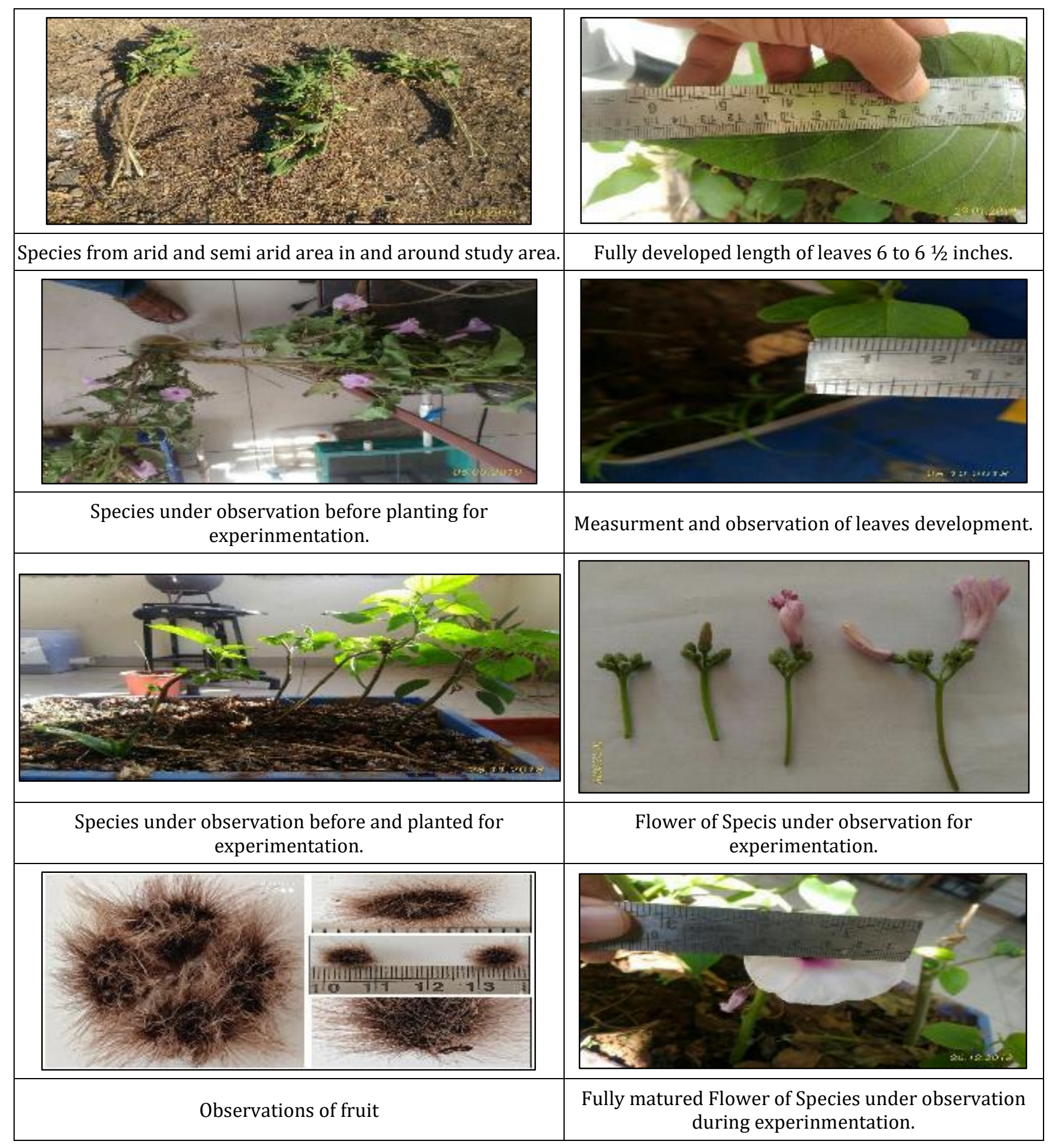




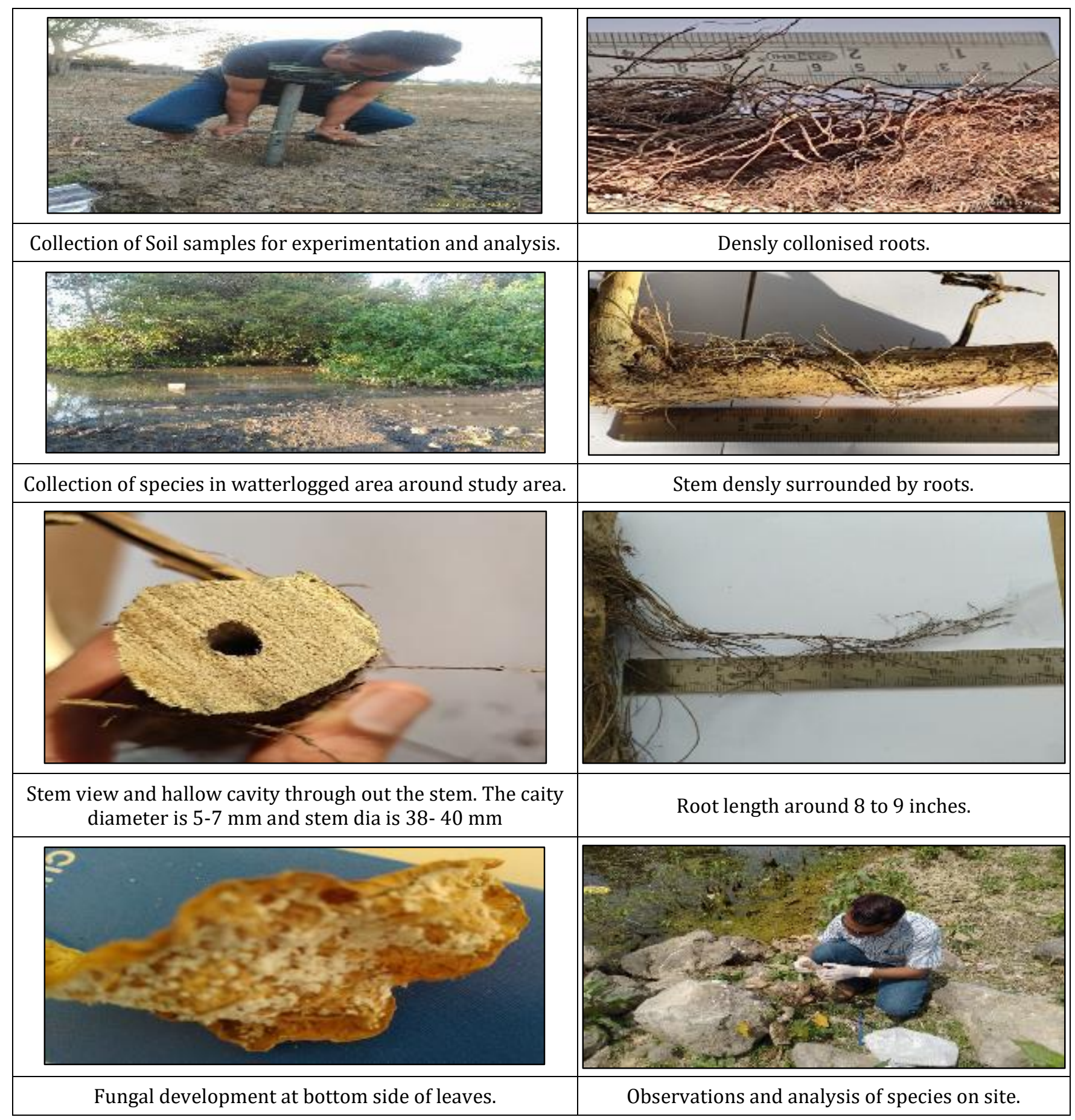

Figure 1 Observations of Ipomoea carnea for outer perspective

\subsection{Observations under microscope}

The matured dried stem are cut with cubical size around $0.15 \mathrm{~mm}$ to put under Scanning Electron Microscope (SEM) to get more inner details about stem cells and analysis of cavities available in stem structure. Similarly the dried root sample was prepared and placed under SEM to analyze the internal root structure and its combination with noncontaminated water sample.

The extensive microscopic views of internal structure of Ipomoea Carnea will be helpful to understand the structural arrangement of stem. The roots of Ipomoea Carnea magnified under SEM varies from 130X to 30000X magnification. 


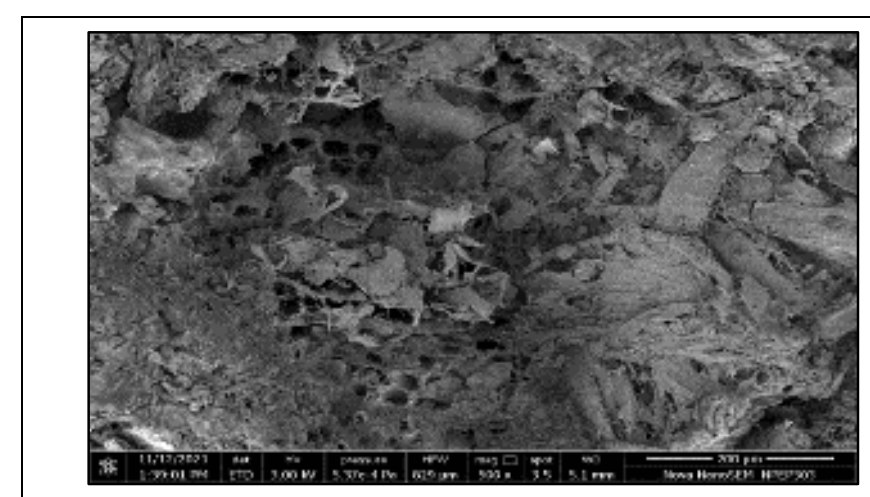

Solid Stem close look at $500 \mathrm{x}$ magnification on top surface.

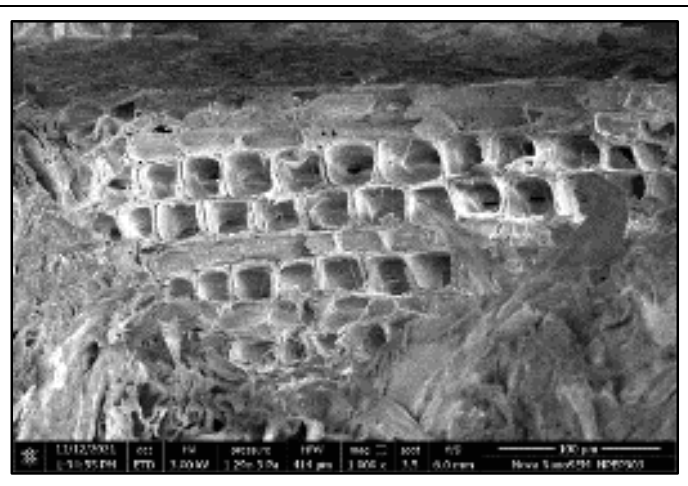

Air pockets and opening within the solid stem body structure magnification at $1000 \mathrm{x}$

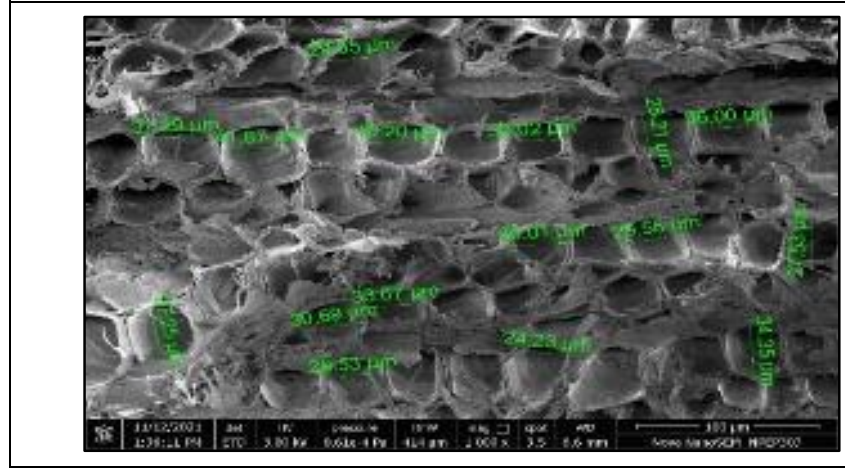

Magnification at $1000 \mathrm{x}$ and observed opening size ranges from $24.23 \mu \mathrm{m}$ to $41.87 \mu \mathrm{m}$

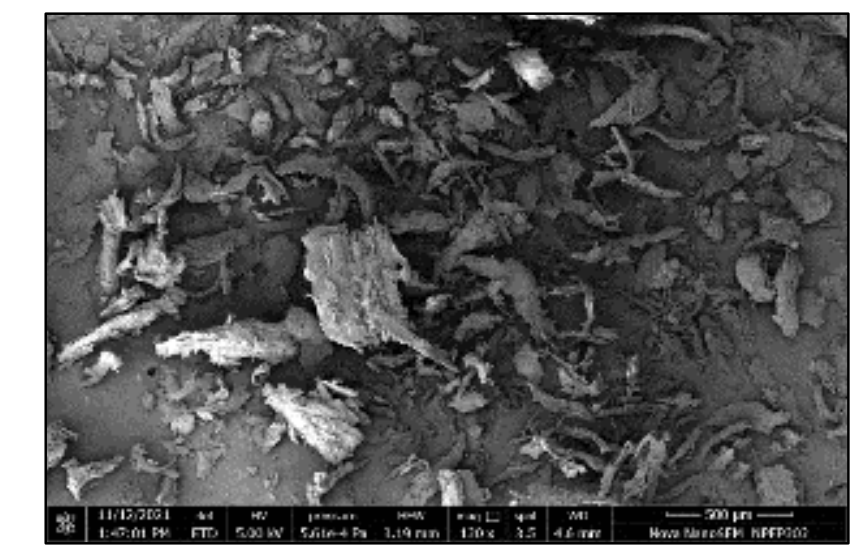

Powdered particles obtained from solid stem magnified at $130 \mathrm{X}$.

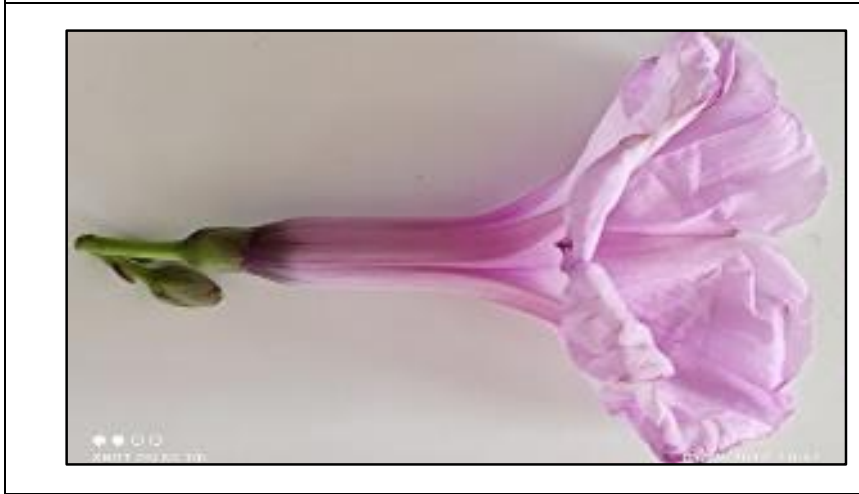

Ipomoea carnea flower under experimental observation

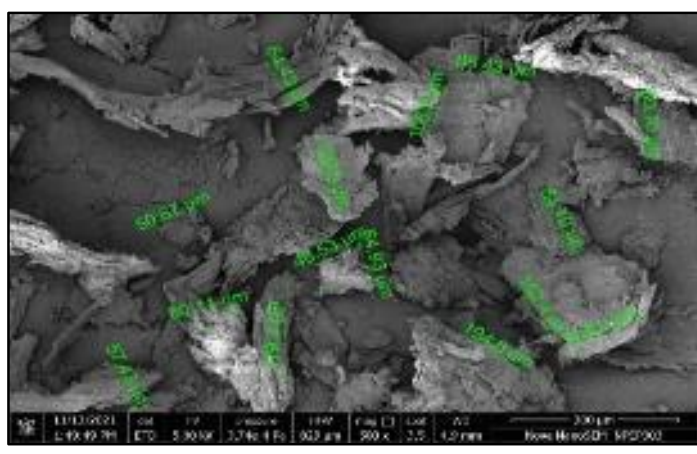

Powdered particles obtained from solid stem magnified at $500 \mathrm{X}$. The size ranges from $48.53 \mu \mathrm{m}$ to $194.6 \mu \mathrm{m}$

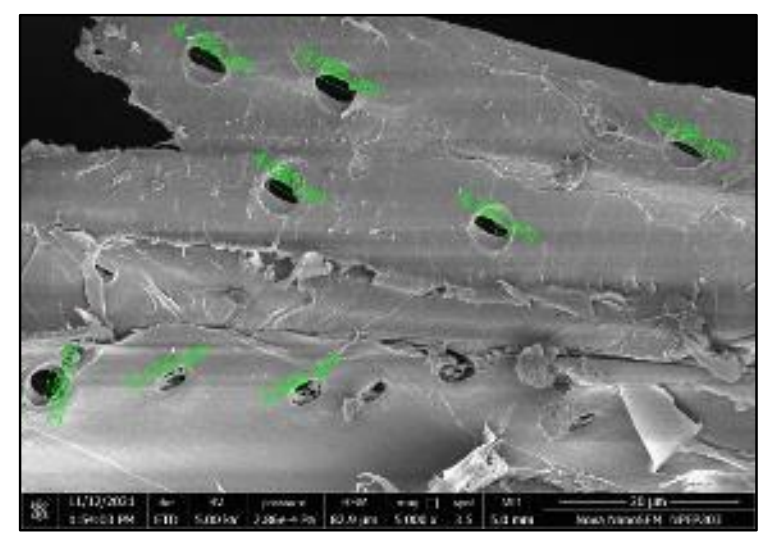

Single particle at $5000 \mathrm{X}$ magnification and has least opening of $3.958 \mu \mathrm{m}$ and maximum of $5.336 \mu \mathrm{m}$

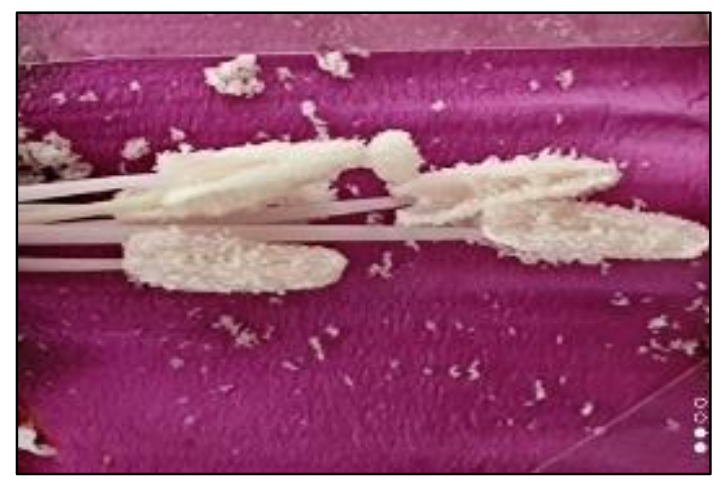

Under cut view of Stamen with anther and filament of Ipomoea carnea with pollen 


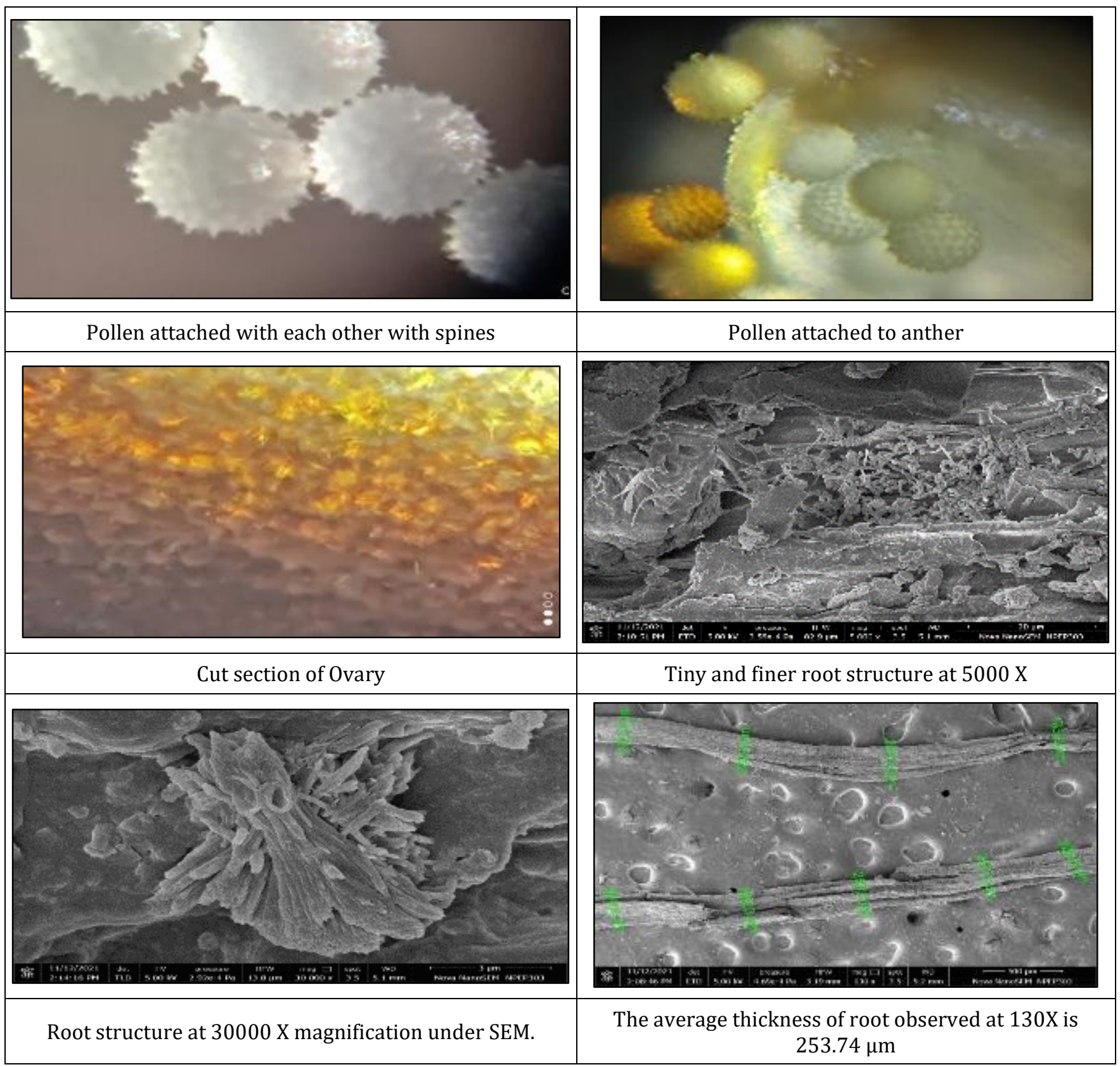

Figure 2 Analytical observations of Ipomoea carnea inner perspective

The flower during and after maturity is observed under simple microscope and captured the magnified images with conventional cameras (MI, Asus and Canon) with magnification from $4 \mathrm{X}$ to $14 \mathrm{x}$ zoom capacity. The details of captured images under SEM are shown in figure 2.

\section{Results and discussion}

The leaf of Ipomoea Carnea is simple, alternate, exstipulate and petiolate. Petiole is cylindrical, attains $4-7.5 \mathrm{~cm}$ length and $2.5-3.0 \mathrm{~mm}$ diameter. The leaf blade is cordate with symmetric base, measures $13-23 \mathrm{~cm}$ in length and $5.5-9.5$ $\mathrm{cm}$ in width, with entire margin and reticulate pinnate venation, slightly hairy on both surfaces, the upper surface is dull green and the lower one is paler [10].

The Bio-Concentration factors (BCF) and reviewed considerable values of Translocation Factors (TF) shown that Ipomoea Carnea has considerable uptake potential for most of the metals. The Ipomoea Carnea that produces the massive biomass and has much high growth rate with immense stress acceptance characteristics. They exhibited improved accumulation and translocation potential for toxic metals like $\mathrm{Cd}, \mathrm{Cr}, \mathrm{Pb}$ and $\mathrm{Ni}$, from roots to the above 
ground parts- stem and leaves. Hence these plant can be used for the phytoremediation of metals from contaminate sites, ecofriendly and natural system $[4,8,13,16,17]$.

Table 1 Description of Ipomoea Carnea Jacq. At s.no 84 of phytokeys [7]

\begin{tabular}{|l|l|c|}
\hline Sr. No. & Particulars & Observations \\
\hline 1 & Erect (subsp. fistulosa) or climbing (subsp. carnea) undershrub & 4 meters \\
\hline 2 & Growing in bunches, stems stout and hollow, canescent leaves & ---- \\
\hline 3 & Leaves petiolate & 8 to $20 \times 3$ to $10 \mathrm{~cm}$ \\
\hline 4 & Petioles & 3 to $8 \mathrm{~cm}$ \\
\hline 5 & Peduncles & 2 to $12 \mathrm{~cm}$ \\
\hline 6 & Sracteoles & 3 to $4 \mathrm{~mm}$ \\
\hline 7 & Secondary peduncles & 3 to $7 \mathrm{~mm}$ \\
\hline 8 & Pedicels & 5 to $15 \mathrm{~mm}$ \\
\hline 9 & Sepals subequal, & 5 to $6 \times 7$ to $8 \mathrm{~mm}$ \\
\hline 10 & Corolla & 6 to $7 \mathrm{~cm} \mathrm{long}$ \\
\hline 11 & Limb & 4.5 to $5 \mathrm{~cm}$ dia. \\
\hline 12 & Capsules & $18 \times 10 \mathrm{~mm}$ \\
\hline 13 & Woolly seeds & 10 to $11 \times 3$ to $4 \mathrm{~mm}$ \\
\hline
\end{tabular}

The fruit has five tenacious sepals and remains of the style at the apex. It has height of about 1 to $1.5 \mathrm{~cm}$, and width of 0.8 to $1.3 \mathrm{~cm}$ and generally comprises four dark brown colored seeds covered with dense hairs. A thin pericarp has thickness about $0.1 \mathrm{~cm}$ with yellowish grey inner surface with fill of smooth and glabrous. The seeds of Ipomoea Carnea has length of $0.4-0.6 \mathrm{~cm}$ and diameter of $0.2-0.3 \mathrm{~cm}$ with dark brown to black color and can be separated from anatropous ovule [10]. It was studied that the concentration of heavy metals in the plant leaf samples is higher than the concentration in the water and soil samples so that Ipomoea Carnea Jacq. Act as a hyper accumulator plant for heavy metals which are present in the polluted soil and water. The plants are exclusively perennial herbaceous species which give relatively more yield of biomass and hence it will prove it usefulness in phytoremediation. $[11,12,13,18]$. These species do not seem to be affected by extreme metal contents and are best promising species for phyto extraction of contaminants $[14,15]$.

\section{Conclusion}

The sociable and multicultural distribution of species reflects on its inherent ability to either circumvent or overcome the adversity itself. It appears, therefore, that urbanization has been a spent force in so far as Ipomoea carnea is concerned in balancing biodiversity $[6,16]$.

Ipomoea Carnea is a folkloric valuable plant and it is used in various activities like Glycosidase Inhibitory Activities, Antioxidant Activity Anti- Inflammatory Activity, Antidiabetic Activity, Wound Healing Activity Antimicrobial Activity, Immunomodulatory Activity, Cardiovascular Activity, and abortifacient, Antifungal Activity, Anticancer and Hepatoprotective Activity etc. The plant shows the occurrence of many active chemical constituents which are responsible for various pharmacological medicinal uses. In future Ipomoea carnea has a leading role for the advancement in noval efficacious medicines [9, 20].

In India Ipomoea Carnea, Jacq. Is a common weed in field and it has better ability of accumulation and translocation of the organic and inorganic matter from liquid and solid phases. The easy availability of this species will be helpful in scientific cultivation by adopting in the engineering applications including wastewater treatments. The adoption will help to produce more biomass through which the byproducts can be manufactured to improve local economical statues especially in rural areas. It has good ability to capture carbon and grows in favorable and hostile conditions without specialized monitoring will helps to contribute in reduction of greenhouse effect. 
Adoption of this plant for ecofriendly and sustainable wastewater treatment will not only economize the treatment but also reduces consumption of energy, chemicals used in advance technology-based wastewater treatments. This technology can be best suited for small towns/ villages where usually no wastewater treatment facility is available. Moreover, local bodies have area available for the same and such installation will be useful to them in highlighting in many cleanliness competitions. The best advantage due to such initiative will be improved health and hygiene of rural population.

\section{Compliance with ethical standards}

\section{Acknowledgments}

This research paper as a part of my ongoing PhD research work under the continuous and motivational guidance of my supportive supervisor, Prof. Dr. Dilip D. Sarode to kept my research work on track, his valuable and constructive inputs made it possible to organize this research paper.

\section{Disclosure of conflict of interest}

This Manuscript have no conflict of interests to declare.

\section{References}

[1] Rehab M. Rizk et al, Assessment of Negative Environmental Impacts of Drainage and Irrigation Canals on Ipomoea carnea Jacq. in Egypt. International Journal of Plant Breeding and Genetics. 2015; 9(3): 143-162.

[2] Mabberley's Plant-book: A Portable Dictionary of Plants, Their Classification and Uses Third Edition, Cambridge Press. 2008; 432-433.

[3] Tapan Adhikari et.al Phytoaccumulation of Lead by Selected Wetland Plant Species, Communications in Soil Science and Plant Analysis. 2010; 41(22): 2623-2632.

[4] I Gunwal et. al. Plants Useful for Phytoremediation Of Soil And Water In India, Asian Journal of Plant and Soil Sciences. 2021; 6(3): 1-8.

[5] Laitonjam Bedabati Chanu, Abhik Gupta, Phytoremediation of lead using Ipomoea aquatica Forsk. In hydroponic solution. 2016; 156: 407-411.

[6] Satish a Bhalerao, Response of Ipomoea carnea Jacq. To the Organic Matter and Water Content of Soils, Nature Environment and Pollution Technology. 2010; 9(4): 805-812.

[7] John RI. Wood, Pablo Muñoz-Rodríguez, A foundation monograph of Ipomoea (Convolvulaceae) in the New World, phytokeys. 2020; 143: 1-823.

[8] Shail Kulshrestha, SK Dabra. Metal uptake Potential of wild plant Ipomoea carnea growing in Contaminated Site, Journal of Emerging Technologies and Innovative Research (JETIR). 2018; 5(1): 1135-1140.

[9] Prasoon Kumar Saxena, Deepak Nanda et. al., A Review On Ipomoea Carnea: An Exploration, International Research Journal of Pharmacy. 2017; 8(6): 1-8.

[10] Eid, Ebrahem \& Shaltout, Kamal \& Al-Sodany, Yassin, Population Ecology of Ipomoea carnea in Egypt, LAP LAMBERT Academic Publishing; 2017;10-11.

[11] Assessment of Negative Environmental Impacts of Drainage and Irrigation Canals on Ipomoea carnea Jacq. in Egypt, International Journal of Plant Breeding and Genetics. 2015; 9(3): 143-162.

[12] Tapan Adhikari , Ajay Kumar, MV Singh, A Subba Rao. Phytoaccumulation of Lead by Selected Wetland Plant Species, Communications in Soil Science and Plant Analysis. 2010; 41(22): 2623-2632.

[13] M Ghosh, SP Singh. A Review on Phytoremediation of Heavy Metals and Utilization of It's by Products Asian Journal on Energy and Environment. 2005; 6(04): 214-231.

[14] Shikha Kumari Pandey Research Scholar, Dr. Tanushree Bhattacharya Assistant Professor \& Dr. Sukalyan Chakraborty Assistant Professor: Metal Phytoremediation Potential of Naturally Growing Plants on Fly Ash Dumpsite of Patratu Thermal Power Station, Jharkhand, India., International Journal of Phytoremediation. 2015.

[15] Yan A, Wang Y, Tan SN, Mohd Yusof ML, Ghosh S and Chen Z. Phytoremediation: A Promising Approach for Revegetation of Heavy Metal-Polluted Land. Front. Plant Sci. 2020; 11: 359. 
[16] Subha M, Srinivas N. Phytoremediation Potential of Weedy plants in Heavy Metal Contaminated Benthic Lake sludge, International Journal of Applied Engineering Research. 2017; 12(14): 4534-4538.

[17] Prabakaran K, Jian Li A. Anandkumar, Zhanrui Leng, Chris B. Zou and Daolin Du. Managing environmental contamination through phytoremediation by invasive plants: A review Ecological Engineering. 2019; 138: 28-37.

[18] Shail Kulshrestha and S. K. Dabral Metal uptake Potential of wild plant Ipomoea carnea growing in Contaminated Site, Journal of Emerging Technologies and Innovative. 2018; 5(1): 1135-1140.

[19] Mungi NA, Kaushik M, Mohanty NP. et al. Identifying knowledge gaps in the research and management of invasive species in India. Biologia. 2019; 74: 623-629.

[20] Sutarman SC, Pamungkas S, Arifin M. Abror, Evaluation of Ipomea carnea Growth Response in Plant Media That was Exposed by Sidoarjo Mud, IOP Conference. Series: Earth and Environmental Science. 2021; (755): 1-5. 